\title{
Model of Consumer Attitude in the Activity of Cause-Related Marketing
}

\author{
Singgih Santoso \\ Faculty of Economics and Business, Duta Wacana Christian University, Yogyakarta, \\ Griya Arga Permai, Jl. Merbabu D 6 Nogotirto Yogyakarta 55291, Indonesia \\ Email: singgih.santoso@gmail.com
}

\section{Basu Swastha Dharmmesta}

Faculty of economics and business, gadjah mada university, Yogyakarta, Universitas Gadjah Mada, Fakultas Ekonomika dan Bisnis, Jl. Humaniora, Bulaksumur, Yogyakarta 55281, Indonesia

Email: dharmmesta@mmugm.ac.id

\section{Bernardinus Maria Purwanto}

Faculty of economics and business, gadjah mada university, Yogyakarta, Universitas Gadjah Mada, Fakultas Ekonomika dan Bisnis, Jl. Humaniora, Bulaksumur, Yogyakarta 55281, Indonesia

Email: bm-purwanto@ugm.ac.id

\section{Doi:10.5901/mjss.2015.v6n4p499}

\section{Abstract}

Company support of social cause, called cause related marketing (CRM), recently has experienced extraordinary growth. Using signalling theory, this study empirically tests a formation of attitude toward alliance model, which consists of impact of attitude toward brand, attitude toward causes, product fit, and brand fit on attitude toward CRM, and evaluate the impact of attitude toward CRM on purchase intention. A $2 \times 2$ factorial design experiment with the use of experience-product was conducted to test hypothesis. The first result is unification of product fit with brand fit into one variable, called fit. The second results is that attitudes toward the cause and fit between partners have significant effect on formation of attitude toward alliance. But hypothesis that attitude toward brand has positive impact on attitude toward CRM is rejected. The third finding is when the model is modified, there is positive and significant direct relation between attitude toward brand and purchase intention.

Keywords: cause related marketing, signalling theory, attitude toward brand, attitude toward cause, brand fit.

\section{Introduction}

The development of social marketing concept (Kotler and Keller, 2009; Kotler and Lee, 2005) forces the marketers to take into consideration social issues and ethics in their marketing activities by balancing profit earning, consumer satisfaction, and public interest. One important issue in social marketing, recently, is environmental preservation with crucial issue of global warming that has negative impacts on many life sectors.

One effort to reduce global warming is by doing energy efficiency that can be done through public education activity in the form of appeal to reduce the use of electronic devices at home or encouragement to use energy-saving home appliances. Recently, a lot of big companies in Indonesia start to have concerns on efforts to reduce global warming through energy-efficiency movement. This brings out two issues that become backgrounds of this study, namely brand alliances activity and special form of that activity which is cause-related marketing (CRM) activity.

Brand alliances strategy, basically, is an activity to unify two or more brands into one new product with the intention of giving new meaning on product offering that is integrated in consumer mind (Walchli, 2007; Erevelles et al., 2008; Wymer and Samu, 2009; Wymer and Sargeant, 2006). The special form of brand alliances is CRM activity which is an alliance activity between a commercial brand with a social organization with the intention to get funding for conducted social activity by taking a certain percentage of sales made (Lafferty and Edmonson, 2009). In CRM activity, non-profit organization will try to reach wider public and to increase public awareness on the organization's existence; while precedence factors for the company are enhancement of company and product image in consumer mind, increasing sales and profit, and success in public relation activities (Varadarajan and Menon, 1988; Wymer and Samu, 2009; Lafferty, 2009). In this study, CRM definition from Varadarajan and Menon (1988) is used as a reference, which is the 
process of formulating and implementing marketing activities that are characterized by an offer from the firm to contribute a specified amount to a designated cause when customers engage in revenue-providing exchanges that satisfy organizational and individual objectives.

This study intends to analyze formation of consumer attitude in alliance activity between a commercial brand with a social organization. In details, this study will test empirically (1) whether attitude toward a commercial brand before the alliance, attitude toward social organization, product category fit, and brand fit in the alliance of a commercial brand with a social activity have effects on consumer attitude toward the alliance, and (2) whether consumer attitude toward an alliance has effect on consumer purchase intention on a commercial brand. By understanding formation process of consumer attitude, it is expected that the model can predict consumer behaviour toward commercial brand applying CRM activity.

\section{Literature Review and Hypothesis Development}

In relation with CRM activities, it is described the use of signaling theory to explain the formation of consumer attitude toward brand of CRM . This theory is based on a concept that buyer and seller in a market have different level and information (Nelson, 1970). The asymmetric information becomes a problem in selling experience product which has characteristic of unobservable quality before the product is purchased and used (Rao and Ruekert, 1994; Kirmani and Rao, 2000; Franke et al., 2004; Huang et al., 2009; Yun et al., 2010).

There are various signals that can be used to give information to consumer; one of which is brand name (Alhabeeb, 2007; Rao et al., 1999; Wernerfelt, 1988). An alliance between an unknown brand and a good reputation social organization can help the brand to get good quality signal from consumer; in the event of no alliance, the brand cannot give quality signal to its consumer that it has good quality. Likewise, an alliance between a social organization that has not been widely recognized by stakeholders and a brand that has a good quality perception in consumer mind can help the social organization to get positive signal in consumer mind.

From the aforementioned discussion, several hypotheses will be developed. The development will be based on formation of consumer attitude that includes three components, namely cognitive, affective, and conative component, and also based on attention on the application of signal theory on the process of attitude formation when a commercial brand that is classified as experience product has an alliance with a social organization.

\subsection{Hypothesis Development}

Research models in CRM studies are developed from researches on brand extension and then from researches on brand alliances. According to James (2006), in line with the start of popularity of brand alliances activities in many countries, research activitity on brand leverage began to shift from research on brand extension to research on brand alliances, which was pionereed by study of Rao and Ruekert (1994) and then followed by several important studies on brand alliances, such as study of Simonin and Ruth (1998) and Baumgarth (2004). With the development of CRM activity, several researches to observe activity of brand alliances in the context of CRM are conducted. Model of Lafferty et al. (2004) that replicates model of Simonin and Ruth (1998) by replacing one commercial brand with non-profit organization explains the impact of alliance between two brands on consumer attitude toward the brand after the brand alliances, and consumer attitude toward brand resulted from the alliance. The various previous models show that there is a strong relation between consumer attitude toward individual brands before alliance and formation of consumer attitude toward brand resulted from the alliance. Likewise, there is also a relation between consumer attitude toward brand resulted from the alliance and consumer purchase intention. The model also includes the important effect of alliance brand fit to formation of consumer attitude toward brand resulted from alliance.

From the literature studies, five research hypotheses are developed:

\subsection{Relation between Variable of Attitude toward Product Brand and Variable of Attitude toward Social Organization with Variable of Attitude toward CRM}

Theory of signaling states that brand name can be functioned as signal of quality of one brand that cannot be observed directly. If a brand has been perceived as having qood quality and the brand has an alliance with other commercial brand or non-commercial brand, consumer tends to judge that alliance product resulted from one brand that has good perception will also have quality not lower than the individual brand before alliance; and good perception on one individual brand will have positive impact on the other brand (Rao and Ruekert, 1994; Wymer and Samu, 2009, Trimble 
and Rifon, 2006; Hajjat, 2003).

The same thing occurs on social organization that is being alliance partner. If a social organization is in alliance with commercial brand that is perceived as having good quality or good philantrophy activity, thus the alliance activity tends to have positive impact on the social organization; conversely, an alliance with commercial brand having bad image will have negative impact on the social organization. Thus, in a CRM activity, name of one social organization can serve as a signal for consumer. The name will guarantee that the organization will choose commercial brand with good reputation because its reputation is being staked. Similarly, name of one brand can be a signal that its reputation will always be maintained by choosing a social organization with good reputation in consumer mind.

From the discussion, two hypotheses can be presented:

$\mathrm{H}_{1}$ : variable of attitude toward brand has positive impact on variable of attitude toward CRM.

$\mathrm{H}_{2}$ : variable of attitude toward cause has positive impact on variable of attitude toward CRM.

\subsection{Relation between Variable of Product Category Fit and Variable of Brand Fit with Variable of Attitude Toward CRM}

In this research, two variables to evaluate brand fit will be used, namely product fit and brand fit. An alliance between two compatible product categories will be responded more positively by consumer compared to an alliance between two noncompatible product categories (Hamlin and Wilson, 2004; Alcaniz, et al.,2010).. Inconsistency of product category can give negative signal to consumer because the commercial company is considered not doing philantrophy activity earnestly. The same thing happens to name fit; a good reputation commercial brand that will spend additional investment, logically, will look for a social organization that can rise its good image in consumer mind or, minimal, the organization will not ruin its good image. Therefore, considering name fit of two brands that has relatively similar image is a logic thing to do in CRM activity.

From the discussion, it can be presented hypotheses as follows:

$\mathrm{H}_{3}$ : variable of product fit has positive impact on variable of attitude toward CRM.

$\mathrm{H}_{4}$ : variable of brand fit has positive impact on variable of attitude toward CRM.

\subsection{Relation between Variable of Attitude Toward CRM with Purchase Intention}

By having alliance with a good reputation social organization, a commercial brand also gives signal of its product reputation to consumers. With the availability of consumers' pro-social attitude and consumers' literal understanding that they have made a donation for social activity by buying the product, this positive signal will be strengthened to be a motivation to consume the commercial brand (Hou et al., 2008; Lafferty and Edmonson, 2009).

From the discussion, it can be presented a hypothesis as follows:

$\mathrm{H}_{5}$ : variable of attitude toward CRM has positive impact on variable of purchase intention.

Based on reviews of several researches and hypotheses explanation, a research model on consumer attitude toward alliance brand can be formulated:

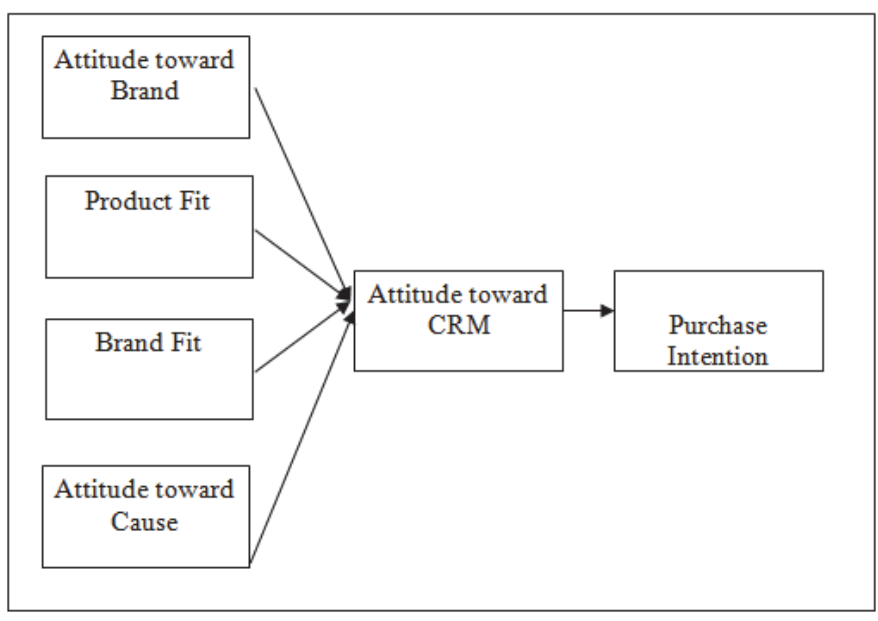

Figure 1. Research Model of Cause Related Marketing (CRM) 


\section{Research Method}

\subsection{The selection of products and brands}

In this study, carried out the process of selecting a commercial product categories and brands, then the determination of social organization. The first pretest conducted to determine the issues that will be the companion issue of energy savings; to seek the opinion of the characteristic variation of the experiment, the issue sought to be lower than the level of urgency of the issue of energy savings. A number of respondents gave ratings on three environmental issues, namely energy conservation, forest conservation and wildlife protection; results show animal protection issues ranked lowest, so the issue becomes the companion issue of energy savings.

Pretest was then performed to find the product category as a companion alliance research issues, namely energy savings; number of respondents again ranked the number of product categories that are categorized as experience products, with the selected category of energy-efficient lighting products and alkaline batteries. The third pretest conducted to find a commercial brand for both categories of products. With emphasis on product quality attributes, a number of brands rated by respondents, with selected results of the Philips brand for the category of energy-efficient lighting products and brands to product categories $A B C$ alkaline batteries.

In contrast to the determination of product categories and brands of products, to social organization, made the determination that the name of social organization active in the environmental activities, namely Greenpeace Indonesia for social organization in the field of energy savings, and WALHI for social organization in the field of protection of endangered species.

\subsection{Experiment Design}

This research tests causality relation between variables in the aforementioned model. Data collected for this research are primary data obtained from experimental activities. The experiment design used in this research is factorial design; because there are 2 (commercial brands) $\times 2$ (social organization), there will be 4 experiment groups. This research uses student samples, which are number of students who have known the commercial brand and the name of social organization that will be allied. The student samples are selected by using random assignment.

The experiment was conducted by mixed-design, which is a combination of between-subject design, because each experiment group will be given different stimulation of alliance between commercial brand and social organization, with within-subject design, because each participant will experience two stages of experiment. The first stage of the experiment is measuring participants' purchase intention toward commercial brand before alliance; while in the second stage, the same participants will be given a stimulation of alliance between commercial brand with social organization, and then their attitude and purchase intention toward the brand after alliance will be measured.

\subsection{Selection of product and brand}

In this research, selection process of commercial brand and social organization is conducted. To select commercial brand, a series of pre-test is conducted. The first pre-test is conducted to decide type of issue that will be a companion of energy-efficiency issue; the result is issue of endangered animal protection. Second pre-test is conducted to select two product categories belonging to experience product and having compatibility to be allied with issue of energy-efficiency; the result is category of energy-efficieny lamp and alkaline battery. Third pre-test is conducted to select name of commercial brand for each product category; the result is brand of Philips for energy-efficiency lamp product and brand of $A B C$ for alkaline battery product. After that, two already-known social organizations are set to have alliance with the two commercial brands, which are Greenpeace Indonesia for social organization in the field of energy-efficiency and WALHI for social organization in the field of endangered animal protection.

\subsection{Experiment Activities}

The previous processes result in four combinations of alliace, namely energy-efficiency lamp product of Philips with Greenpeace Indonesia, alkaline battery product of ABC with WALHI, energy-efficiency lamp product of Philips with WALHI, and alkaline battery product of ABC with Greenpeace Indonesia. Then, manipulation check is conducted to observe whether participants give different respond on the four types of stimulant, which is differentiated to check the fit between product category and name of social organization and to check the fit between commercial brand name and 
name of social organization. Result of manipulation check shows that participants can differentiate both combination fit of product category and combination of brand names with social organization in alliance.

After participant groups established, stimulant materials and questionnaires which include operational variables with proven validity and realibility are prepared. The next process is distributing the experiment materials to participants. For the first stage of the experiment, the material is a questionnaire containing the variables in the consumer's purchase intention commercial brand before CRM activities. In the second stage of experiments, the material consists of five sections. The first part is a questionnaire about the initial attitude of consumers towards the brand's commercial and social organizations before the CRM activities. The second part is the stimuli that contain CRM activity, which is accompanied by a questionnaire about the suitability of the product category, brand appropriateness, and consumer attitudes toward these CRM activities. The third part is a questionnaire on consumer purchase intention after CRM activities. Each construct was measured by a number of indicators are represented by seven-point semantic differential (Lafferty, 2004).

The collected data then processed to test the model of consumer attitude formation in CRM activity by using analysis tool of Structural Equation Modelling (SEM). The research model will be tested with some criteria of goodness of fit generally used; among others are Chi-Square, Goodness of Fit Index (GFI), Adjusted Goodness of Fit Index (AGFI), Root Mean Square Error of Approximation (RMSEA), Non-Normed Fit Index atau Tucker Lewis Index (TLI), Normed Fit Index (NFI), and Comparative Fit Index (CFI) (Hair et al., 2006, Hooper et al., 2008).

\section{Research Results and Discussion}

The experiment activities with student participants were conducted on Septembet to October 2011. The experiment was conducted in mixed design, which is a combination of between-subject design and within-subject design. In the first day of the experiment, participants filled a questionnaire about one certain commercial brand which can be Philips energyefficiency lamp or ABC alkaline battery. One week after, the same participants received stimulant materials and filled questionnaire that measures attitude and purchase intention of participants toward the two brands in alliance. Participants that had filled certain commercial brand in the first season would fill stimulant materials of the alliance between the brand with social organization. From 392 former participants with a requirement that the participants have to take the two stages of the experiment and follow all the activities, there were 315 primary data that were eligible for further processing.

\subsection{Analysis of Changes in Purchase Intention}

The first stage of the analysis is the analysis of changes in participants' purchase intention, which is the difference of participants' purchase intention score before and after one commercial brand conduct CRM activity. The following is the results of changes in participants' purchase intention score:

Table 1. Changes in Participants' Purchase Intention Score

\begin{tabular}{|c|c|c|}
\hline \multirow{2}{*}{ Question } & \multicolumn{2}{|c|}{ Purchase Intention Score } \\
\cline { 2 - 3 } & Before & After \\
\hline Considering to Buy Now & 5,02 & 5,64 \\
\hline Intention to Buy Now & 4,73 & 5,52 \\
\hline Definitely to Buy Now & 4,16 & 5,08 \\
\hline Likely to Buy in the Future & 5,28 & 5,65 \\
\hline Definitely to Buy in the Future & 4,50 & 5,16 \\
\hline Intention to Buy in the Future & 5,12 & 5,47 \\
\hline Mean Score & $\mathbf{4 , 8 1}$ & $\mathbf{5 , 4 2}$ \\
\hline
\end{tabular}

The t-test of paired data shows the significance difference score (at significance level 5\%) of before-and-after CRM activiy, so that it can be concluded that CRM activity has positive impact on participants' purchase intention toward commercial brand. If observed from score comparison for each before-and-after-alliance purchase intention variable indicator, there is an increase in average score of six purchase intention variable indicators. This shows that the CRM activity increase participants' positive attitude toward commercial brand. With an increase in participants' purchase intention has been proven to exist, then, test of the research model is conducted. 


\subsection{Analysis on Research Model}

The former model of CRM can be seen on figure 2:

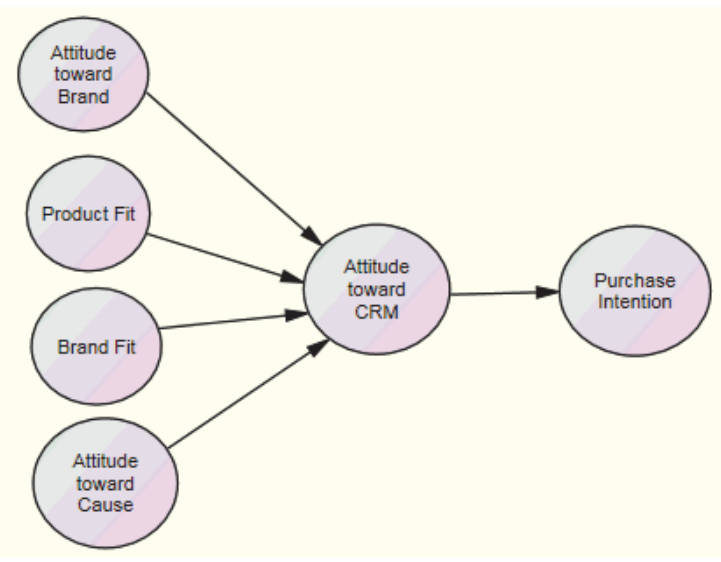

Figure 2. Model of Cause Related Marketing (CRM)

Before the model is being tested with analysis tool of SEM, factor analysis is conducted to see grouping of observed variables. Result of factor analysis show that variable of product fit and variable of brand fit are in the same factor. This shows that both variables are rated as the same construct by the participants so they can be named as fit variable. Therefore, the model, then, is modified by unifying the two variables.

The findings of this research shows consumers do not distinguish between the suitability of the product with the conformity mark; to suggest that there is only one construct, the construct of conformity. On the relationship between the concept of generic schemes, schemes and scheme brand products (Helmig et al., 2007), a brand of the alliance would respond positively if the two products of the two schemes have the suitability of individual brands. Greenpeace Indonesia and WALHI are two well-known name in Indonesia and is considered to have a good reputation. This causes the participants did not distinguish clearly between the scheme and scheme brand products from both the social organization; Greenpeace Indonesia and WALHI considered social product names and brand names as well as social activities. Similarly to commercial brands; participants identified the Philips as an energy-efficient lighting, and not one of the many brands of lights. Similarly, participants considered the same as the ABC brand and product brand alkaline battery. Because participants did not distinguish clearly the product scheme and the scheme of commercial brand and brand of social organization, then the combination of two names that do not form a separate alliance and form a similar construct.

Combination of the two variables results in a new model as seen on figure 3 :

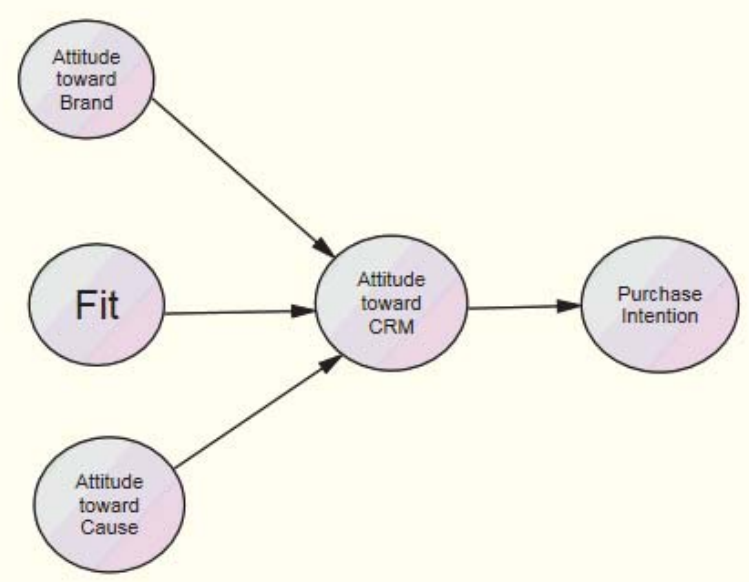

Figure 3. Model of Cause Related Marketing (2) 
From the model, by using 315 primary data from the experiment activities, results of model fit test are as follows:

Table 2. Results of Model Fit Test

\begin{tabular}{|c|c|c|}
\hline Fit Index & Acceptable Threshold Levels & Result \\
\hline$X^{2} / \mathrm{df}$ & $2-3$ & 3,570 \\
\hline RMSEA & $<0,07$ & 0,090 \\
\hline GFI & $>0,90$ & 0,770 \\
\hline AGFI & $>0,90$ & 0,731 \\
\hline TLI & $>0,95$ & 0,847 \\
\hline CFI & $>0,95$ & 0,860 \\
\hline NFI & $>0,90$ & 0,817 \\
\hline
\end{tabular}

From the comparison between model fit criteria and results of data procession, it can be seen that requirements of the alliance model cannot be met. Therefore, indicators existed in each latent variables are changed into only one indicator that is called as composite indicator. Then, relation between variables is presented in the form of path diagram as follows:

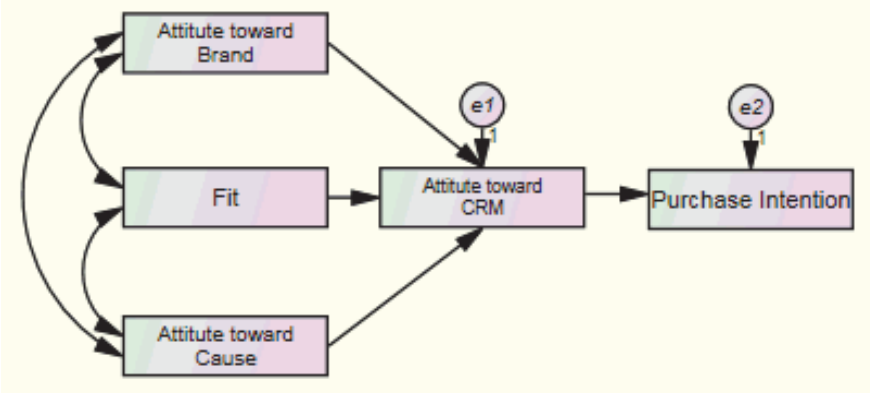

Figure 4. Display of CRM Model In the Form of Path Diagram

From the path diagram, results for model feasibility test are obtained:

Table 3. Results of Feasibility Test on Path Diagram

\begin{tabular}{|c|c|c|}
\hline Fit Index & Acceptable Threshold Levels & Result \\
\hline$X^{2} / \mathrm{df}$ & $2-3$ & 48,678 \\
\hline RMSEA & $<0,07$ & 0,390 \\
\hline GFI & $>0.90$ & 0,870 \\
\hline AGFI & $>0.90$ & 0,352 \\
\hline TLI & $>0,95$ & 0,089 \\
\hline CFI & $>0.95$ & 0,727 \\
\hline NFI & $>0,90$ & 0,726 \\
\hline
\end{tabular}

Table 3 shows that all numbers obtained from the calculation cannot meet criteria of feasibility. But on the display of table of modification index as follows:

Table 4. Modification Index

\begin{tabular}{|l|c|}
\hline Suggested Variable Relation & Modification Index \\
\hline PIC (Purchase Intention) $\rightarrow$ CC (Attitude toward Cause) & 9,179 \\
\hline PIC (Purchase Intention) $\rightarrow$ FITC (Fit) & 12,532 \\
\hline PIC (Purchase Intention) $\rightarrow$ BRC (Attitude toward Brand) & 109,481 \\
\hline
\end{tabular}

Since the scale of the modification index is 109,481 , there is a suggestion to perform model modification by connecting variable of attitude toward brand with variable of purchase intention. From the composite index that has been modified, 
results of test of model feasibility are obtained:

Table 5. Results of Feasibility Test on Modified Composite Model

\begin{tabular}{|c|c|c|}
\hline Fit Index & Acceptable Threshold Levels & Result \\
\hline$X^{2} / \mathrm{df}$ & $2-3$ & 0,823 \\
\hline RMSEA & $<0,07$ & 0,000 \\
\hline $\mathrm{GFI}$ & $>0.90$ & 0,998 \\
\hline $\mathrm{AGFI}$ & $>0.90$ & 0,984 \\
\hline $\mathrm{TLI}$ & $>0,95$ & 1,000 \\
\hline $\mathrm{CFI}$ & $>0.95$ & 1,000 \\
\hline $\mathrm{NFI}$ & $>0,90$ & 0,997 \\
\hline
\end{tabular}

The table shows that the model has met the requirements of feasibility test. Ratio value of RMSEA, GFI, AGFI, TLI, CFI and NFI has met the specified criteria. Therefore, it can be said that the aforementioned alliance model has passed the feasibility test; all index indicated good fit between hypothesized model and empirical data.

The following is the display of alliance model that has been modified:

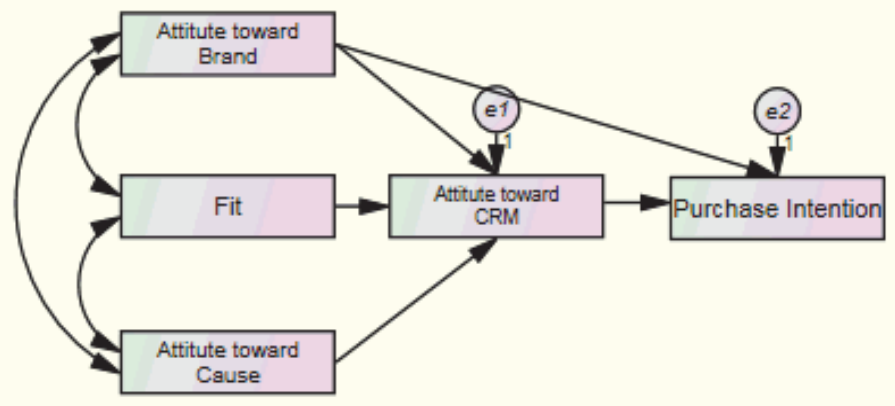

Figure 5. Display of Path Diagram Model of Cause Relatede Marketing after Modification

The next step is doing test on regression coefficient in structural model. The results of the test can be seen on Table 6:

Table 6. Results of Test of Structural Model

\begin{tabular}{|c|c|c|c|c|}
\hline Variable Relation & Regression Coefficient & S.E. & C.R & Prob. \\
\hline Attitude toward Brand $\rightarrow$ Attitude toward Alliances & $-0,123$ & 070 & $-1,764$ & ,078 \\
\hline Fit $\rightarrow$ Attitude toward Alliances & 0,701 & 073 & 9,668 &, 000 \\
\hline Attitude toward Cause $\rightarrow$ Attitude toward Alliances & 0,544 & 079 & 6,912 &, 000 \\
\hline Attitude toward Alliances $\rightarrow$ Purchase Intention & 0,171 & 040 & 4,256 &, 000 \\
\hline Attitude toward Brand $\rightarrow$ Purchase Intention & 0,822 & 061 & 13,540 &, 000 \\
\hline
\end{tabular}

The summary table shows that not all hypotheses tested are emprically supported. In model of consumer attitude in CRM activity, attitude toward commercial brand, individually, has no effect on consumer attitude toward CRM. Meanwhile, consumer attitude toward social organization individually, and the fit level between commercial brand and social organization that allied has significant effect on consumer attitude toward CRM. And consumer attitude toward CRM product has significant effect on consumer purchase intention toward the alliance product.

The non-significant relation between attitude toward brand and attitude toward CRM may be caused by the existence of good perception from consumers for both commercial brands, namely Philips and ABC. The signal theory states that the name of brand can be a sign of quality of a product; a CRM activity with a good reputation social organization shows the quality and reputation of the brand, so that it is expected to be an additional signal that will increase image of the product. However, for utilitarian product that is more oriented to product function and feature, alliance with social organization do not make good reputation commercial brand to be better perceived by consumer. Consumer sees that Philips energy-efficieny lamp and $A B C$ alkaline battery as utilitarian products with good reputation 
and quality, so that addition of a brand of social organization does not change the perception significantly.

By doing model modification to get better value of feasibility test, result that gives contribution on CRM research is obtained. Significant result between the two variables is obtained by connecting variable of attitude toward brand with variable of purchase intention. The result shows that relation between variables in CRM activity is influenced by a lot of factors, especially type of product that can be sorted as hedonic-utilitarian product. This research uses product of lamp and battery that can be classified as utilitarian product because the products are more oriented on fulfilling the need for lighting and other activities that need energy; product of energy-efficiency lamp is oriented on using electrical energy as optimal as possible, while product of alkaline battery is also oriented on efficiency of energy use. When will be used or after being used, product of energy-efficiency lamp and alkaline battery do not evoke emotion (affection) of consumer significantly, or the use causes effect of guilty feeling from consumer (Strahilevitz, 2003; Strahilevitz and Myers, 1998); even, the consumer will feel that he has taken part in positive activities, such as saving electrical energy or utilization of energy resources to the fullest.

\section{Conclusion}

General resume of this study is that the discovery of different test results from previous studies. The first finding is the availability of unification of variable of product fit with variable of brand fit into one variable that is called with fit variable. Data analysis shows that participants consider the two variables as a unity and have significant effect on formation of attitude toward alliance. The second finding is that in the activity of alliance between a commercial brand with a social organization, formation of attitude toward CRM is not influenced by consumer initial attitude toward commercial brand; instead, the formation of attitude toward CRM is influenced by the fit between commercial brand and social organization, and consumer attitude toward social organization. Result of the test also shows the availability of positive effect between consumer attitude toward CRM and consumer purchase intention toward the alliance product. The third finding is when the model is modified; there is positive and significant direct relation between variable of attitude toward brand and variable of purchase intention.

The insignificant effect of variable of attitude toward brand on variable of attitude toward CRM, which accompanied by significant effect of variable of attitude toward brand on variable of purchase intention can be caused by two things. First is the existence of positive attitude toward commercial brand that has been formed in the past. Acitivity of brand alliance with social organization that is expected to give positive signal is, in fact, having insignificant effect on formation of consumer attitude; the consumer will buy commercial brand that is considered to have good quality, accompanied or not accompanied by alliance activity.

The second cause is related with type of products in alliance. This research uses product of energy-efficiency lamp and alkaline battery that are classified as utilitarian products, which are oriented on the fulfillment of basic need and the use of the product functionally. The activity of consuming utilitarian products does not create consumer's guilty feeling, either before, is, or after consuming the brand because the consumer more sees the usefulness and function of the product to accomplish certain works. For that, activity to give donation to a social activity does not significantly encourage altruistic behavior of consumer.

Another conclusion is for a brand that is well known and considered a good reputation, has no impact on alliance activity increases positive attitudes of consumers who have been there. Similarly, for products with large utilitarian elements, less effective CRM activities to influence the target market.

\subsection{Implications of the Advanced Studies}

For the future, to do research on the use of signal theory of CRM activities by using the product with the dimensions of hedonic experience are dominant; research can also be made to launch a new brand that has not been widely recognized and alliances with social organizations that have had a good reputation. In addition, the research model can also be tested further by incorporating a number of moderating variables, such as gender, education level, the level of one's religiosity and so on. Other research topics that can be developed is the use of services in the CRM, as well as the possibility of an alliance of more than one commercial brand, good for a similar product or other product categories.

\section{References}

Alhabeeb, M.J. (2007). Consumers' cues for product quality: an application of the signalling theory. Academy of Marketing Studies, 12 , 1-5. 
Baumgarth, C. (2004). Evaluations of co-brands and spill-over effects: further empirical results. Journal of Marketing Comunications, 10, 115-131.

Erevelles, S., Horton, V., \& Fukawa, N. (2008). Understanding b2c brand alliances between manufacturers and suppliers. Marketing Management Journal, (Fall), 32-46.

Franke, G. R., Huhmann, B. A., \& Mothersbaugh, D. L. (2004). Information content and consumer readership of print ads: A comparison of search and experience products. Journal of the Academy of Marketing Science, 32, 20-31.

Hair, J. F., Black, W. C., Babin, B. J., Anderson, R. E., \& Tatham, R. L. (2006). Multivariate data analysis (6rd ed.). New Jersey: Pearson Education, Inc., (Chapter 10).

Hajjat, M. M. (2003). Effect of cause-related marketing on attitudes and purchase intentions: the moderating role of cayse involvement and donation size. Journal of Nonprofit and Public Sector Marketing, 1, 93-109.

Hamlin, R. P. \& Wilson, T. (2004). The impact of cause branding on consumer reactions to products: does product/cause 'fit' really matter? Journal of Marketing Management, 20, 663-681.

Helmig, B., Huber, J. A., \& Leeflang, P. (2007). Explaining behavioural intentions toward co-branded products. Journal of Marketing Management, 23, 285-304.

Hooper, D., Coughlan, J., \& Mullen, M. R. (2008). Structural equation modelling: guidelines for determining model fit, The Electronic Journal of Business Research Methods, 6, 53-60.

Hou, J. D., Lanying, D., \& Jianfeng, L. (2008). Cause's attributes influencing consumer's purchasing intention: empirical evidence from China. Asia Pasific Journal of Marketing, 20, 363-380.

Huang, P., Lurie, N. H., \& Mitra, S. (2009). Searching for experience on the web: an empirical examination of consumer behavior for search and experience goods. Journal of Marketing, 73, 55-69.

James, D. O. (2006). Extention to alliance: Aaker and Keller's model revisited. Journal of Product and Brand Management, 15, 15-22.

Kirmani, A. \& Rao, A. R. (2000). No pain, no gain: a critical review of the literature on signalling unobservable product quality. Journal of Marketing, 64, 66-79.

Kotler, P. \& Keller, K. L. (2009). Marketing Management (13th ed.). New Jersey: Pearson Education Inc., (Chapter 1).

Kotler, P. \& Lee, N. (2005). Best of breed: when it comes to gaining a market edge while supporting a social cause, corporate social marketing leads the pack. Social Marketing Quartely, 11, 91-103.

Lafferty, B. A. (2009). Selecting the right cause partners for the right reasons: the role of importance and fit in cause-brand alliances. Psychology \& Marketing, 26, 359-382.

Lafferty, B. A. \& Edmonson, D. R. (2009). portraying the cause instead of the brand in cause related marketing ads: does it really matter? Journal of Marketing Theory and Practice, 17,129 - 143.

Lafferty, B. A., Goldsmith, R. E. \& Hult, G. T. M. (2004). The impact of the alliance on the partners: a look at cause-brand alliances. Psychology \& Marketing, 21, 409-531.

Nelson, Philip (1970), "Information and Consumer Behavior," The Journal of Political Economy, Vol. 78: 311-329.

Rao, A. R., Qu, L. \& Ruekert, R. W. (1999). Signaling unobservable product quality through a brand ally. Journal of Marketing Research, $\mathrm{XXXVI,} \mathrm{258-268.}$

Rao, A. R. \& Ruekert, R. W. (1994). Brand alliances as signals of product quality. Sloan Management Review, (Fall), 87-97.

Simonin, B. L. \& Ruth, J. A. (1998). Is a company known by the company it keeps? Assesing the spill over effects of brand alliances on consumer brand attitudes. Journal of Marketing Research, 35, 30-42.

Strahilevitz, M. (2003). The effect of prior impressions of a firm's ethics on the success of a cause-related marketing campaign: do the good look better while the bad look worse. Journal of Nonprofit and Public Sector Marketing, 11, 77-92.

Strahilevitz, M. \& Myers, J. G. (1998). Donation to charity as purchase incentives: how well they work may depend on what you are trying to sell. Journal of Consumer Research, 24, 434- 446.

Trimble, C. S. \& Rifon, N. J. (2006). Consumer perceptions of compability in cause-related marketing messages. International Journal Nonprofit Voluntary Section Marketing, 11, 29-47.

Varadarajan, P. R. \& Menon, A. (1988). Cause-related marketing: a coalignment of marketing strategy and corporate philanthropy. Journal of Marketing, 52, 58-74.

Walchli, S. B. (2007). The effect of between-partner congruity on consumer evaluation of co-branded products. Psychology Marketing, 24, 947-973.

Wernerfelt, B. (1988). Umbrella branding as a signal of new product quality: an example of signalling by posting a bond. Journal of Economics, 19, 458-466.

Wymer, W. \& Samu, S. (2009). The influence of cause marketing associations on product and cause brand value. International Journal of Nonprofit and Voluntary Sector Marketing, 14, 1-20.

Wymer, W. \& Sargeant, A. (2006). Insights from a review of the literature on cause marketing. International Review on Public and Non Profit, 3, 9-21.

Yun, W., Nakayama, M \& Sutcliffe, N. (2010), The impact of age and shopping experiences on the classification of search, experience, and credence goods in online shopping. Information System e-Business and Management, May 2010. 